\title{
Modern opleiden: oude wijn in nieuwe zakken?
}

Citation for published version (APA):

Smeenk, F. W. J. M. (2014). Modern opleiden: oude wijn in nieuwe zakken? voor een toekomstbestendige gezondheidszorg. Maastricht University. https://doi.org/10.26481/spe.20140424fs

Document status and date:

Published: 24/04/2014

DOI:

$10.26481 /$ spe.20140424fs

Document Version:

Publisher's PDF, also known as Version of record

\section{Please check the document version of this publication:}

- A submitted manuscript is the version of the article upon submission and before peer-review. There can be important differences between the submitted version and the official published version of record.

People interested in the research are advised to contact the author for the final version of the publication, or visit the DOI to the publisher's website.

- The final author version and the galley proof are versions of the publication after peer review.

- The final published version features the final layout of the paper including the volume, issue and page numbers.

Link to publication

\footnotetext{
General rights rights.

- You may freely distribute the URL identifying the publication in the public portal. please follow below link for the End User Agreement:

www.umlib.nl/taverne-license

Take down policy

If you believe that this document breaches copyright please contact us at:

repository@maastrichtuniversity.nl

providing details and we will investigate your claim.
}

Copyright and moral rights for the publications made accessible in the public portal are retained by the authors and/or other copyright owners and it is a condition of accessing publications that users recognise and abide by the legal requirements associated with these

- Users may download and print one copy of any publication from the public portal for the purpose of private study or research.

- You may not further distribute the material or use it for any profit-making activity or commercial gain

If the publication is distributed under the terms of Article $25 \mathrm{fa}$ of the Dutch Copyright Act, indicated by the "Taverne" license above, 


\section{Maastricht University}

Oratie

prof.dr. Frank W.J.M. Smeenk

Faculty of Health, Medicine and Life Sciences

\section{Modern opleiden: Oude wijn in nieuwe zakken? voor een toekomstbestendige gezondheidszorg}


Mijnheer de Rector Magnificus, leden van de Raad van Bestuur van het Maastricht Universitair Medisch Centrum + en het Catharina ziekenhuis, leden van het College van Toezicht, hooggeleerde gasten, beste collega's, familie, vrienden en overige aanwezigen, hartelijk dank voor uw komst naar Maastricht om mijn oratie te aanhoren.

\section{Inleiding}

Vandaag staan de medische specialistische vervolgopleidingen centraal en in het bijzonder de vernieuwingen die de afgelopen jaren hebben plaatsgevonden.

Na een korte inleiding over de geschiedenis van het medisch onderwijs, wil ik U de veranderingen die zich op landelijk niveau hebben voorgedaan en hoe deze zich vertaald hebben op locaal en regionaal niveau schetsen. Vervolgens wil ik stil staan bij de verbeteringen die nog mogelijk zijn en tot slot een blik op de toekomst richten.

Een goede gezondheid wordt over het algemeen als een groot, zo niet het grootste goed beschouwd. Daarom is het van groot maatschappelijk belang dat wij dokters opleiden die berekend zijn op de taken die hen wachten, namelijk zorgen voor een zo goed mogelijke kwaliteit van de gezondheidszorg en dat voor een betaalbare prijs.

In het afgelopen decennium hebben zich op dit gebied belangrijke vernieuwingen voorgedaan. Om deze vernieuwingen te rechtvaardigen wordt er nog al eens een vergelijking gemaakt met hoe deze opleiding in het verleden zou zijn geweest. Namelijk hard werken, geen tijd voor reflectie of begeleiding, en vooral aandacht voor medische competenties en niet voor de, in ons vak zo belangrijke, niet medische vaardigheden, zoals communicatie en samenwerking.

Dit is echter niet hoe ik mijn eigen opleiding in de jaren 80 heb ervaren. Natuurlijk, wij hadden geen arbeidstijdenbesluit en het was hard werken, maar dit had wel tot gevolg dat je in korte tijd veel ervaring opdeed. Ook de begeleiding op de werkvloer heb ik altijd als ruim voldoende ervaren. Er was voldoende tijd voor feedback, zij het dat deze niet genotuleerd werd behalve dan bij de gebruikelijke jaarlijkse voortgangsgesprekken. Ook was er, zo heb ik zelf ervaren, voldoende aandacht voor de niet medische competenties. Zo werd ik aan het eind van mijn opleiding betrokken bij de ontwikkeling van transmurale afspraken met en de nascholing voor huisartsen. Zo werd ongemerkt gewerkt aan de competentie samenwerking. Daar kijk ik met een goed gevoel op terug en dit heeft er mede toe bijgedragen dat ik hier nu kan staan. Tot zover mijn eigen ervaringen.

\section{Geschiedenis medisch onderwijs}

Als we vervolgens kijken naar de ontwikkelingen van het medisch onderwijs in de afgelopen eeuwen dan kunnen we een paar mijlpalen onderscheiden.

In de tijd van prof. Adrien Pelerin, de eerste hoogleraar geneeskunde in de Anatomiae en Chirugiae in Maastricht benoemd in 1738, vond de gezondheidszorg plaats door enerzijds chirurgijnen, die kleine uitwendige ingrepen uitvoerden en anderzijds door 
doctores medicinae die in tegenstelling tot de chirurgijnen vaak een academische opleiding hadden genoten en ziekten van de inwendige organen behandelden. In deze tijd vond het voorbereidend onderwijs voor de universitaire opleidingen meestal plaats in de zogenaamde Illustere Scholen. Een gymnasium kon 'illustre', dit is bijzonder gemaakt worden, door er een bovenbouw voor hoger onderwijs aan toe te voegen met hoogleraren als docent. In Maastricht waren dit het Jezuïeten college en het Latijns lyceum. Het geneeskunde onderwijs aan deze scholen had een voorbereidend, propadeutisch karakter. ${ }^{1}$ Het vervolgonderwijs vond in die tijd plaats in gilde-achtige structuren waarbij men de volgende fases kon onderscheiden: die van leerling, gezel en meester, waarbij men het vak leerde door het af te kijken van de meester en het vervolgens na te doen. ${ }^{2} \mathrm{U}$ ziet dit in deze ets uit 1614 van het Rotterdams gilde van chirurgijnen fraai weergegeven, waarbij de meester een onderbeensamputatie verricht en de gezel en leerling toekijken. ${ }^{3}$

Figuur 1. Ets Rotterdams gilde der chirurgijnen.

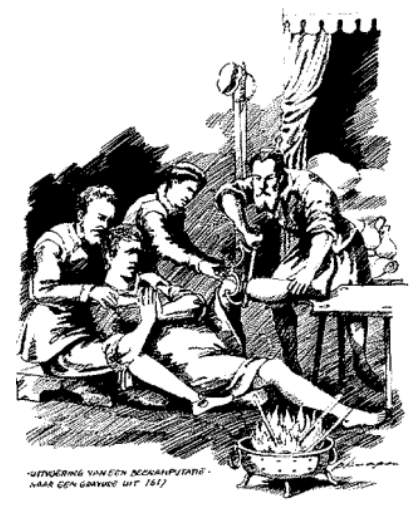

Het eerste belangrijke markeringspunt in de geschiedenis van het medisch onderwijs treffen we aan rond 1910 met het uitkomen van de Flexner, en korte tijd later de WelchRose en Goldmark rapporten over de structurering van het onderwijs in de gezondheidszorg in de Verenigde Staten. Deze rapporten hebben er ook in Europa toe geleid dat het medisch onderwijs geacademiseerd werd in universiteiten met een verschuiving van 'op de praktijk gebaseerd' naar 'op kennis gebaseerd' onderwijs. ${ }^{4}$ Een volgende mijlpaal was de invoering van het probleem gestuurd onderwijs in de jaren 70. Kenmerkend voor het probleem gestuurd onderwijs is dat de student centraal staat en dat in kleine groepen een academisch of klinisch probleem bestudeerd wordt. Deze universiteit heeft van meet af aan deze ontwikkeling omarmd en verder ontwikkeld. Zij heeft daarmee internationaal een toonaangevende rol gespeeld. Tot slot hebben we rond de eeuwwisseling de ontwikkeling naar het competentie gericht onderwijs meegemaakt. Daar wil ik graag met $u$ nu nader op ingaan voor wat betreft de medische specialistische vervolgopleidingen.

De medische specialistische vervolgopleidingen

Voor 2005 waren deze vooral gericht op het verkrijgen van medische vaardigheden. De opleidingen waren weinig gestructureerd en er werd weinig gedaan aan formatieve-, 
dan wel summatieve toetsing. De opleidingen waren vooral intern georiënteerd, waardoor de kwaliteit van de opleidingen onderling nogal eens kon wisselen.

Dit alles overziend, zouden we kunnen veronderstellen dat dit aanleiding gegeven zou kunnen hebben tot minder goed functionerende dokters en vervolgens tot een mindere kwaliteit van de gezondheidszorg. Toch lijkt dat mee te vallen:

Als we namelijk kijken naar de kwaliteit van de medische gezondheidszorg in Nederland dan staan we vanaf 2008 op de eerste plaats van de European Health Consumer Index, een index die de kwaliteit van zorg beoogt te meten. ${ }^{5}$ Bovendien wordt dit bereikt voor kennelijk een schappelijke prijs, want als we alleen kijken naar de kosten voor de curatieve gezondheidzorg dan treffen we Nederland pas op de $8^{\text {ste }}$ plaats aan. ${ }^{6}$ Dat de kosten voor zorg in Nederland in totaal toch de hoogste zijn van Europa komt vooral door de uitgaven aan de niet curatieve sector.

Figuur 2. European Health index scores landen Europa 2013.

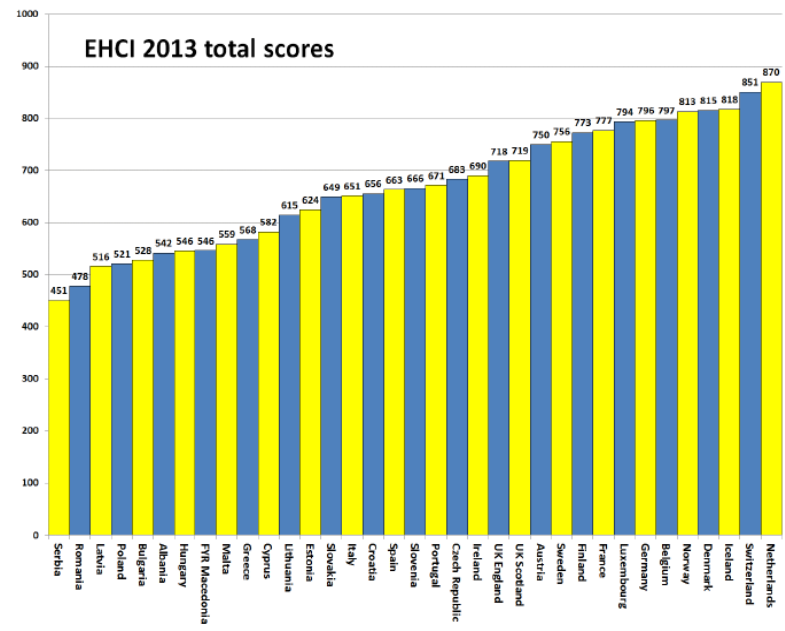

Figuur 3 Zorguitgaven als \% van het BBP in 2009

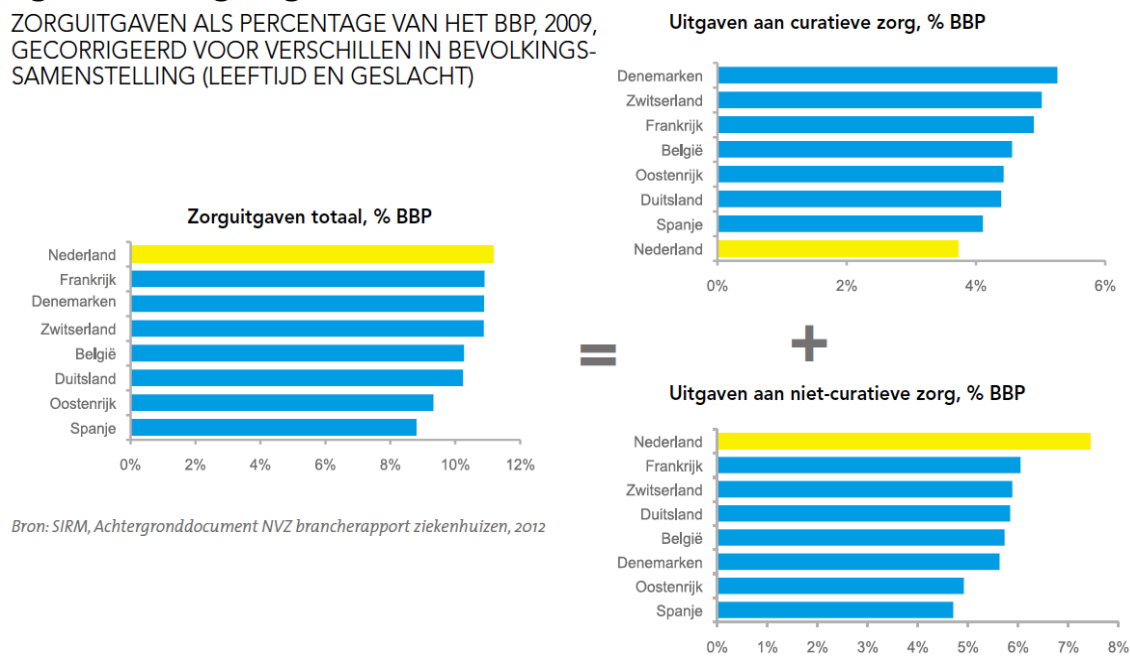

Gelet op het voorgaande zou men zich de vraag kunnen stellen: was de vernieuwing van de opleiding met alle aandacht voor de niet medische competenties dan wel nodig? Deden we het als opleiders voor die tijd al niet intuïtief goed. Was de vernieuwing dus 
toch niet meer oude wijn in nieuwe zakken? De titel die ik, wellicht enigszins provocatief, aan mijn oratie heb meegegeven en die sommigen ons willen laten doen geloven. Ik heb er dan ook een groot vraagteken aan toegevoegd omdat we naar mijn mening deze vraag volmondig met nee moeten beantwoorden. Ik zal dat in mijn verdere betoog toelichten.

Dat deze modernisering toch hard nodig was had te maken met verschillende factoren:

- Allereerst een veranderende maatschappij; de patiënt is mondiger geworden, heeft meer kennis o.a. door toegang tot het internet en er is een evidente vraag naar het afleggen van verantwoording van ons handelen. Verder maakt de toename van de levensverwachting dat het aantal patiënten met vaak meerdere chronische aandoeningen zal toenemen. Al deze ontwikkelingen zorgen ervoor dat er een groter beroep gedaan zal worden op onze niet-medische vaardigheden, zoals communicatie en maatschappelijk handelen.

- Vervolgens veranderingen in het medische domein zelf; ten opzichte van vroeger zijn de behandelmogelijkheden enorm toegenomen, ze zijn complexer en er is een toenemende centralisatie van bepaalde behandelingen. Dit vereist van artsen dat zij veel meer dan voorheen met elkaar moeten samenwerken, niet alleen binnen het ziekenhuis maar ook in netwerken buiten het eigen ziekenhuis. Immers als organisaties en mensen niet goed met elkaar samenwerken, kan men geen optimaal resultaat verwachten, zoals $\mathrm{u}$ in dit filmpje ziet samengevat. Dit domein is tegenwoordig ook zo snel in beweging dat dokters meer nog dan voorheen moeten leren zichzelf bij te blijven scholen om up-to-date te kunnen blijven om zo verantwoorde zorg te kunnen blijven verlenen. Deze competentie van een 'levens-lang-leren' is dan ook voor elke arts een must geworden.

- Tot slot is ook de dokter zelf veranderd. De huidige generatie heeft andere werkvrije tijd behoeftes en er is een toenemende feminisering van het beroep. Dit alles vereist andere vaardigheden, bijvoorbeeld hoe zorgen we voor de continuïteit van de zorg indien de parttime werkende dokter niet meer de continue factor is voor de patiënt en er dus meer overdrachtsmomenten zijn met potentieel meer mogelijkheden tot verlies van essentiële informatie.

Al deze veranderingen dragen ertoe bij dat van de huidige arts veel meer verwacht wordt dan het hebben van adequate medische vaardigheden alleen.

En dat er nog steeds verbetering mogelijk is moge onder andere ook blijken uit de volgende observaties:

- De gebleken praktijkvariatie in Nederland, waarmee bedoeld wordt dat zonder duidelijke reden er grote verschillen waarneembaar zijn in aantallen ingrepen per regio. ${ }^{7}$ Als voorbeeld ziet $U$ hier de praktijkvariatie voor hernia operaties weergegeven, waarbij in de meer donker gekleurde gebieden kennelijk veel meer operaties verricht worden dan in de meer licht gekleurde gebieden. Dit duidt bepaald niet op een optimale/uniforme zorg voor hernia patiënten in Nederland. 
- Verder nemen de klachten in de gezondheidszorg zeker niet af. Deze hebben in verreweg de meeste gevallen betrekking op problemen in de communicatie en/of samenwerking, waarvan u hier een paar recente voorbeelden ziet die de landelijke media gehaald hebben.

Figuur 4. Aantal lumbale hernia operaties in Nederland.

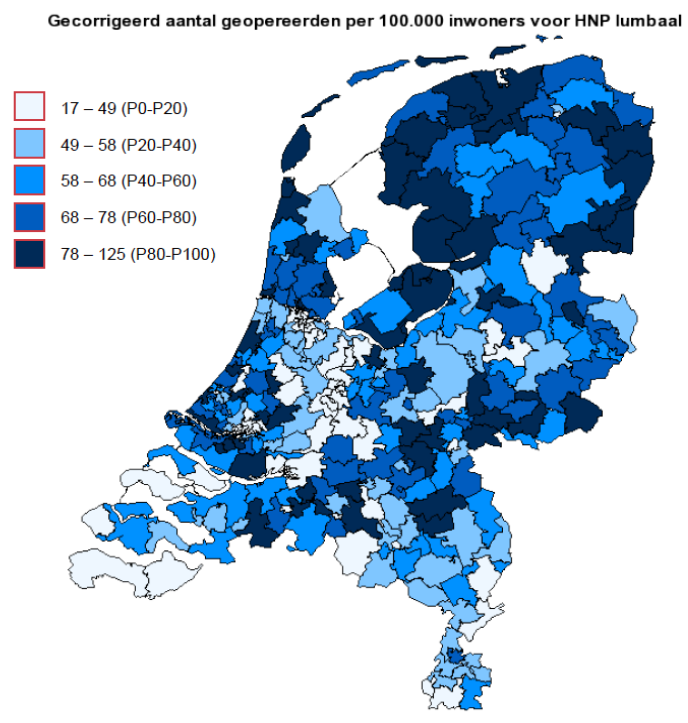

Dit besef heeft er toe geleid dat er destijds door het Centraal College volop ingezet werd op een complete herziening van alle medische specialistische vervolgopleidingen, met veel meer aandacht voor deze, voor ons functioneren als arts belangrijke, niet medische competenties.

Regelgeving met betrekking tot medische specialistische vervolgopleidingen Voor ik nu verder ga is het voor een goed begrip noodzakelijk dat ik, voor hen die hier niet bekend mee zijn, kort inga op hoe één en ander met betrekking tot de regelgeving voor wat betreft het opleiden en registreren van artsen in Nederland is geregeld. Het zal u duidelijk zijn dat dit van groot maatschappelijk belang is omdat hierdoor voor de maatschappij gegarandeerd wordt dat men erop kan vertrouwen dat de arts waartoe men zich went voldoende capabel is.

In dit kader kunnen we onderscheid maken tussen enerzijds het regelgevende en anderzijds het handhavende orgaan. Voorheen hadden de 3 verschillende bloedgroepen in de geneeskundige vervolgopleidingen, de medisch specialisten, de huisartsgeneeskundige - en de sociaal geneeskundige beroepen hun eigen regelgevende en handhavende organen, respectievelijk de zogenaamde colleges en de registratie commissies. De colleges zijn recent samengevoegd in het College Geneeskundig Specialismen, het CGS en de registratie commissies in de Registratiecommissie Geneeskundig Specialismen, het RGS.

Het CGS, doet voorstellen aan de Minister van VWS met betrekking tot de eisen waar de medische specialistische vervolgopleidingen aan moeten voldoen. Deze worden bij 
goedkeuring door de Minister vastgelegd in een algemeen geldend deel, het Kaderbesluit (KB) en een specifiek deel, het Specifieke Besluit (SB), alleen geldend voor het desbetreffende specialisme. Na vaststelling hebben deze Besluiten kracht van wet. De Registratiecommissie Geneeskundig Specialismen, de RGS, is het handhavende orgaan dat aan de hand van de regelgeving van het CGS, controleert of opleidingsinstellingen voldoen aan de eisen, of zij specialisten die klaar zijn met hun opleiding kan registeren, en vervolgens elke 5 jaar vaststelt of zij voldoen aan de eisen voor herregistratie. Op deze wijze wordt zo goed mogelijk gepoogd aan de maatschappij te garanderen dat een arts voldoende bekwaam is om zijn beroep uit te oefenen. Als oud-lid en oud vice-voorzitter van de voorloper van de RGS, de MSRC, heb ik in het afgelopen decennium veel mogen leren van het visiteren en beoordelen van opleidingen. Met dit systeem hebben we een redelijk uniek systeem in de wereld. Wij zijn namelijk één van weinige landen in Europa die een wettelijk verplicht systeem voor nascholing en herregistratie hebben voor medisch specialisten.

Figuur 5. Landen in Europa met een verplicht wettelijk systeem voor nascholing.

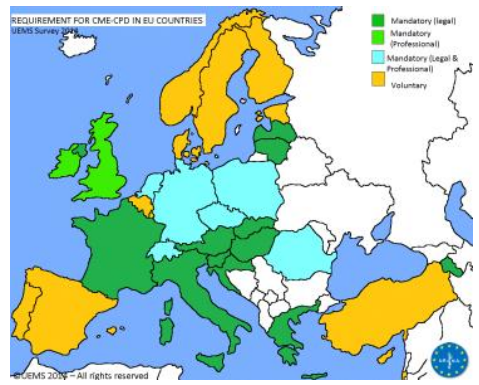

Figuur 6. Landen in Europa met een verplicht herregistratiesysteem.

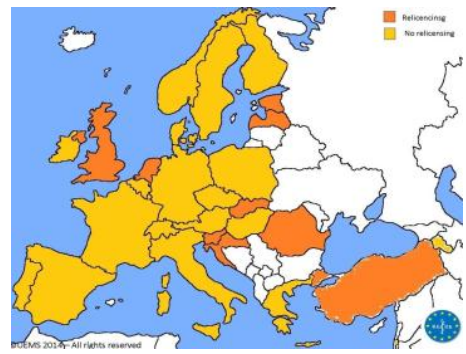

\section{Herziening van de regelgeving}

$\mathrm{Nu}$ wil ik met u terugkeren naar de herziening van de medische specialistische vervolgopleidingen. Duidelijk was dat er in de opleidingseisen naast de aandacht voor de medische vaardigheden, meer aandacht moest komen voor de niet medische vaardigheden. Daarbij heeft men zich internationaal georiënteerd en kwam men al snel uit bij een initiatief dat in 1993 in Canada gestart was: het zogenaamde Canmeds initiatief van de Royal College of Physicians and Surgeons in Canada, waarbij CanMeds staat voor Canadian Medical Education Directives for Specialists. Aan medewerkers in de gezondheidszorg en de bevolking werd gevraagd welke vaardigheden artsen zouden moeten bezitten. Dit leverde 7 kerncompetenties: medische handelen, samenwerking, 
communicatie, maatschappelijk handelen, organisatie, professionaliteit, en kennis en wetenschap. In 2005 werden deze kerncompetenties nog eens geherdefinieerd en momenteel is men met een update voor 2015 bezig. $^{8}$

Figuur 7. De CanMeds competenties.

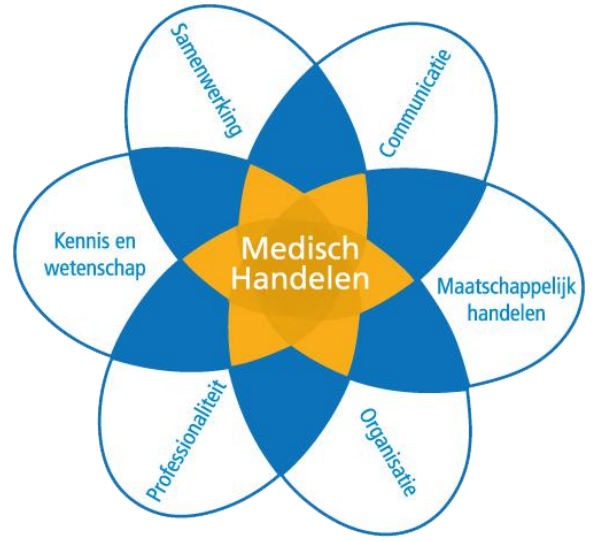

Besloten werd dit raamwerk voor de Nederlandse situatie over te nemen. Daarmee werden deze generieke niet medische competenties opgenomen in het Kaderbesluit en zo geldend voor iedere medisch specialistische vervolgopleiding. Vervolgens dienden de wetenschappelijke verenigingen van alle specialismen hun Specifiek Besluit en opleidingsplan te herzien, waarin heldere eindtermen benoemd moesten worden, niet alleen in het medische domein maar ook voor de niet medische competenties. Als voorzitter van het Concilium heb ik voor de longgeneeskunde mogen meewerken aan deze vernieuwing van de opleiding tot longarts. Zo ontstond het competentie gerichte opleiden, waarbij de nadruk bleef liggen op het goede van het verleden namelijk het verkrijgen van de medisch vaardigheden door het leren op de werkplek, maar nu wel met een adequate vooral formatieve feedback, en voldoende aandacht voor de niet medische competenties.

Figuur 8. De piramide van Miller.

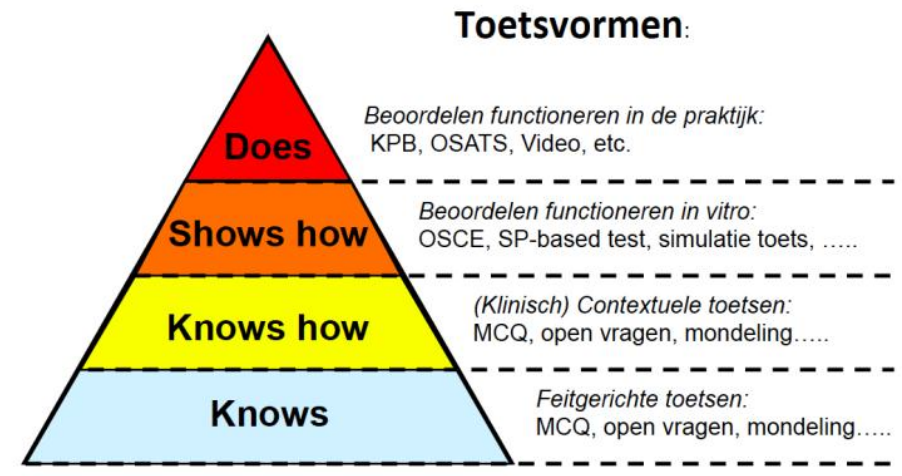

Als we nu het leren onder de loep nemen dan kunnen we volgens Miller verschillende niveaus onderscheiden, die elk op verschillende manieren getoetst kunnen worden. We onderscheiden daarbij het 'kennis' niveau, het 'weten hoe' niveau, het niveau van 'voordoen hoe het zou moeten', en het echte 'uitvoeringsniveau', het in de praktijk bij 
een echte patiënt laten zien hoe het moet. ${ }^{9}$ Dit laatste is in onze opleidingen uiteraard vooral van belang. We hebben natuurlijk niets aan een dokter die je precies kan vertellen hoe je een blinde darm operatie zou moeten uitvoeren, maar die zelf de handvaardigheid daarvoor niet bezit. Vandaar dat toetsing vooral op dit laatste niveau plaats vindt door middel van het uitvoeren van een verplicht aantal klinische praktijk beoordelingen en beoordelingen van technische vaardigheden. Daarbij is het van belang dat we ons realiseren dat één beoordeling natuurlijk geen natuurgetrouw beeld kan geven van de werkelijkheid, maar dat vele beoordelingen tezamen wel een goede validiteit hebben. ${ }^{10,11}$

We kunnen dit vergelijken met het aantal pixels waarmee een foto wordt afgebeeld, hoe meer pixels hoe beter het beeld.

Daarnaast wordt er jaarlijks verplicht een kennistoets afgenomen. Dit alles dient vastgelegd en geaggregeerd te worden in een persoonlijk portfolio, waarmee de opleider en de assistent in opleiding, tegenwoordig aios genoemd, de voortgang in de opleiding kunnen beoordelen en op grond daarvan nieuwe doelen kunnen uitzetten. Een voorbeeld hiervan ziet $\mathrm{u}$ in dit spinnenweb weergegeven, waarbij alle beoordelingen van een bepaalde competentie zijn samengevoegd tot een gemiddelde en dit ook vergeleken kan worden met het gemiddelde van de groep. We kunnen dan in één oogopslag zien hoe een aios functioneert.

Figuur 9. Spinnenweb met overzicht van de compententieniveaus aios.

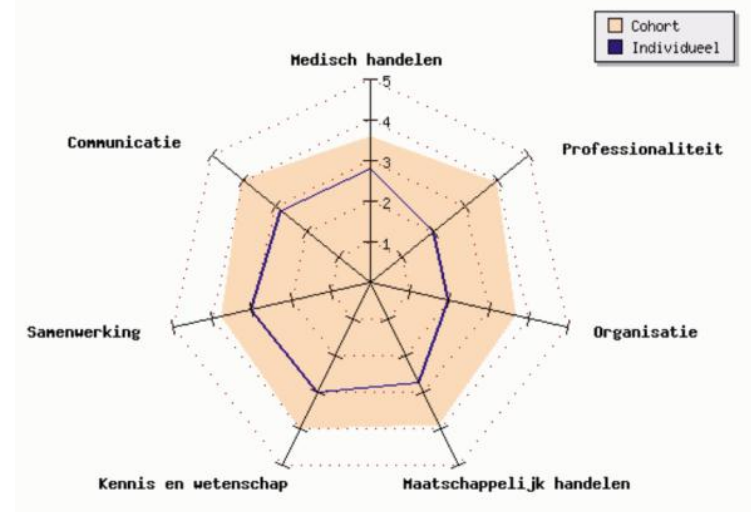

Als we dit nu vergelijken met het opleiden van voor 2005 dan kunnen we de belangrijkste veranderingen als volgt samenvatten: in tegenstelling tot de situatie van voor 2005 zijn de eindtermen en toetsingscriteria nu helder beschreven, is de gegeven feedback meer specifiek, wordt er nu expliciet aandacht besteed aan de niet-medische competenties, is de opleidingsduur door het competentie gerichte opleiden in principe flexibel geworden en is de docentrol helderder beschreven. ${ }^{12} \mathrm{Al}$ met al dus zeker geen oude wijn in nieuwe zakken, maar een evidente vernieuwing in het opleiden, waardoor in de toekomst een betere borging van de kwaliteit van de medisch specialist mogelijk is geworden. 
Tot zover de landelijke ontwikkelingen, maar nu de praktijk. Hoe zijn wij als opleiding longgeneeskunde in het Catharina ziekenhuis gevaren. Midden jaren 90 hebben we als maatschap de opleiding als één van onze speerpunten in ons beleidsplan opgenomen, waarbij we 3 belangrijke onderdelen hebben onderscheiden:

1. Het leren op de werkvloer;

2. Het geven van niet patiënt gebonden onderwijs; en

3. Wetenschappelijk onderzoek.

Door drukte op de werkvloer bleek het moeilijk om invulling te geven aan deze laatste 2 onderdelen. Om deze zaken mogelijk te maken hebben we daarom bewust voor een uitbreiding van de maatschap gekozen. Hierdoor werd het mogelijk een compleet onderwijs curriculum te implementeren en kon het wetenschappelijk onderzoek vorm krijgen. Dit laatste heeft geleid tot een zestal promoties, mede-geïnitieerd vanuit onze afdeling. Dit heeft geleid tot een bestendige onderzoekslijn naar COPD en osteoporose in samenwerking met de afdeling longgeneeskunde van het MUMC+ onder leiding van prof. Wouters. Deze onderzoeksgroep is nu ook uitgebreid met prof. van den Bergh, ook verbonden aan deze universiteit en het VieCurie ziekenhuis en prof. MacNee, vanuit de Universiteit van Edinburgh.

Op één van deze onderzoeken wil ik graag met u wat nader ingaan omdat het fraai het belang van een aantal niet medische competenties illustreert. In 2013 promoveerde aan deze Universiteit Annelies Lucas op haar onderzoek naar de effecten van de ondersteuning van een astma/COPD dienst voor de huisarts bij de diagnostiek en behandeling van astma en COPD patiënten in de eerste lijn. ${ }^{13}$ In haar onderzoek toonde zij aan dat wanneer de longarts de gegevens van het longfunctie onderzoek combineert met het klinisch beeld van de patiënt dat hij schriftelijk toegezonden kreeg, de conclusies van deze beoordeling valide zijn en goed overeenkomen met die van een echte 'live' beoordeling door de longarts, zoals bij een echt consult. Ook wanneer het volgende advies gegeven werd: 'Er wordt een discrepantie gevonden tussen de longfunctie bevindingen en de klachten. Denk aan een andere diagnose', en dat was in meer dan de helft van de beoordelingen het geval, dan bleek dit in $64 \%$ van de gevallen te leiden tot een relevante alternatieve of bijkomende diagnose. Dat dit vaak voorkwam behoeft geen verbazing: immers vrijwel alle longziekten presenteren zich met klachten van hoesten, sputum opgeven, en/of kortademigheid. Maar dit hoeft zeker niet allemaal COPD of astma te zijn.

Dit onderzoek illustreert een aantal belangrijke algemene aspecten die ook voor de medische opleidingen belangrijk zijn, namelijk:

1. Het belang van het kunnen herkennen van de variatie die zich in de ziektebeelden kunnen voordoen, immers slechts een minderheid van de patiënten zullen zich presenteren met precies dezelfde klachten zoals die in de leerboeken beschreven staan. Dit vereist voldoende expositie aan de verschillende ziektebeelden op de werkvloer.

2. Het op peil blijven houden van de kennis van de (patho)fysiologie en het klinisch redeneren. Kunnen de bevindingen van het aanvullende onderzoek de klachten 
van de patiënt wel verklaren? Of is er misschien toch iets anders aan de hand dan het aanvullend onderzoek ons wil laten geloven?

3. Het belang van een goede samenwerking tussen artsen, niet alleen in het eigen domein (voor ons het ziekenhuis), maar ook over deze grenzen heen.

4. Het belang van een goede reflectie op het eigen functioneren. Mijns inziens een eerste vereiste om een goede arts te kunnen zijn. Immers zonder deze eigenschap zullen we onszelf nooit kunnen verbeteren.

Figuur 10. Het belang van reflectie.

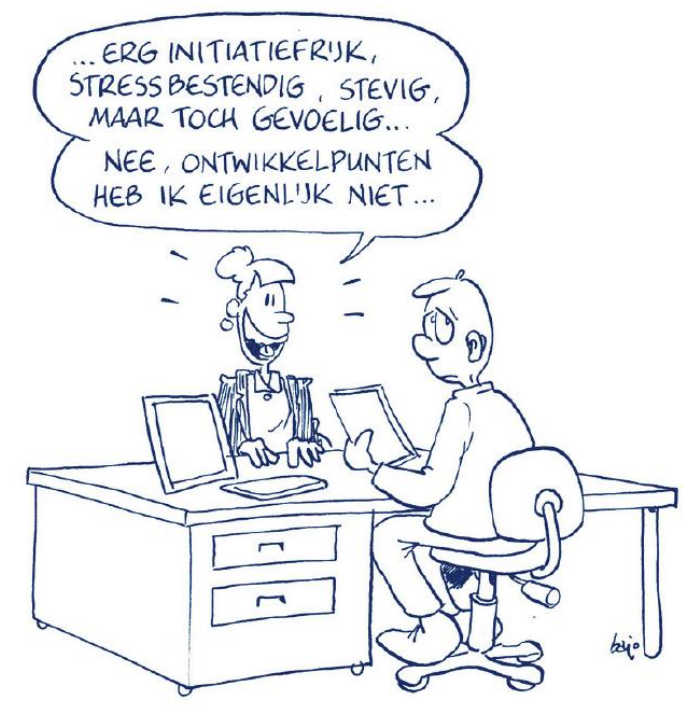

Dit wordt ook fraai geïllustreerd aan een patiënte die ik twee maanden geleden op mijn polikliniek zag in verband met kortademigheidklachten die ze sinds 2 maanden had. De huisarts had longfunctie onderzoek gedaan dat paste bij de diagnose COPD en had haar met de daarvoor bestemde medicatie behandeld. Dit had echter onvoldoende effect op haar klachten. Volgens de richtlijn COPD zou patiënte daarmee in aanmerking komen voor longrevalidatie. Omdat er echter een discrepantie bestond tussen de ernst van de klachten en de ernst van de gevonden longfunctiestoornissen werd patiënte verwezen voor verdere diagnostiek.

Figuur 11. CT angio patiënt.

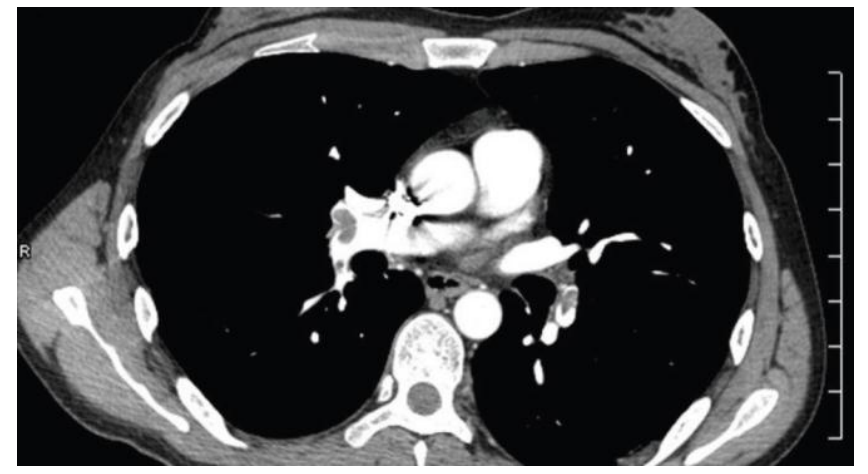

Deze dia laat u zien wat er bij patiënte aan de hand was, namelijk stolsels in de longslagaderen, longembolieën dus. Na behandeling hiervan verdwenen haar klachten. 
Deze casus laat $U$ duidelijk het belang van een goede reflectie zien, namelijk klopte mijn eerste diagnose wel en het belang van een goede samenwerking tussen huisarts en longarts. Was deze er niet geweest dan was het maar de vraag of deze patiënte dit later nog had kunnen navertellen.

\section{Locale veranderingen - het opleidingsziekenhuis}

Dan wil ik nu met u overgaan naar wat de vernieuwing van de medische specialistische vervolgopleidingen heeft betekend voor ons ziekenhuis als opleidingsinstelling. Immers opleiden doe je, als vakgroep niet alleen, ook de instelling heeft een belangrijke voorwaarden scheppende functie.

Zoals al eerder aangegeven bestond er een systeem van externe visitatie door de MSRC, nu de RGS, om er zeker van te zijn dat de opleidingen aan de vereisten zoals vastgelegd in het KB en SB voldeden. Dit systeem van visiteren en controleren had nogal eens een zogenaamde varkenscyclus tot gevolg waarbij opleidingen net een jaar voor de geplande visitatiedatum de puntjes op de 'i' gingen zetten, waarna na de erkenning alle goede intenties veelal weer verflauwden.

Figuur 12. Interne kwaliteitscyclus opleidingen Catharina ziekenhuis.

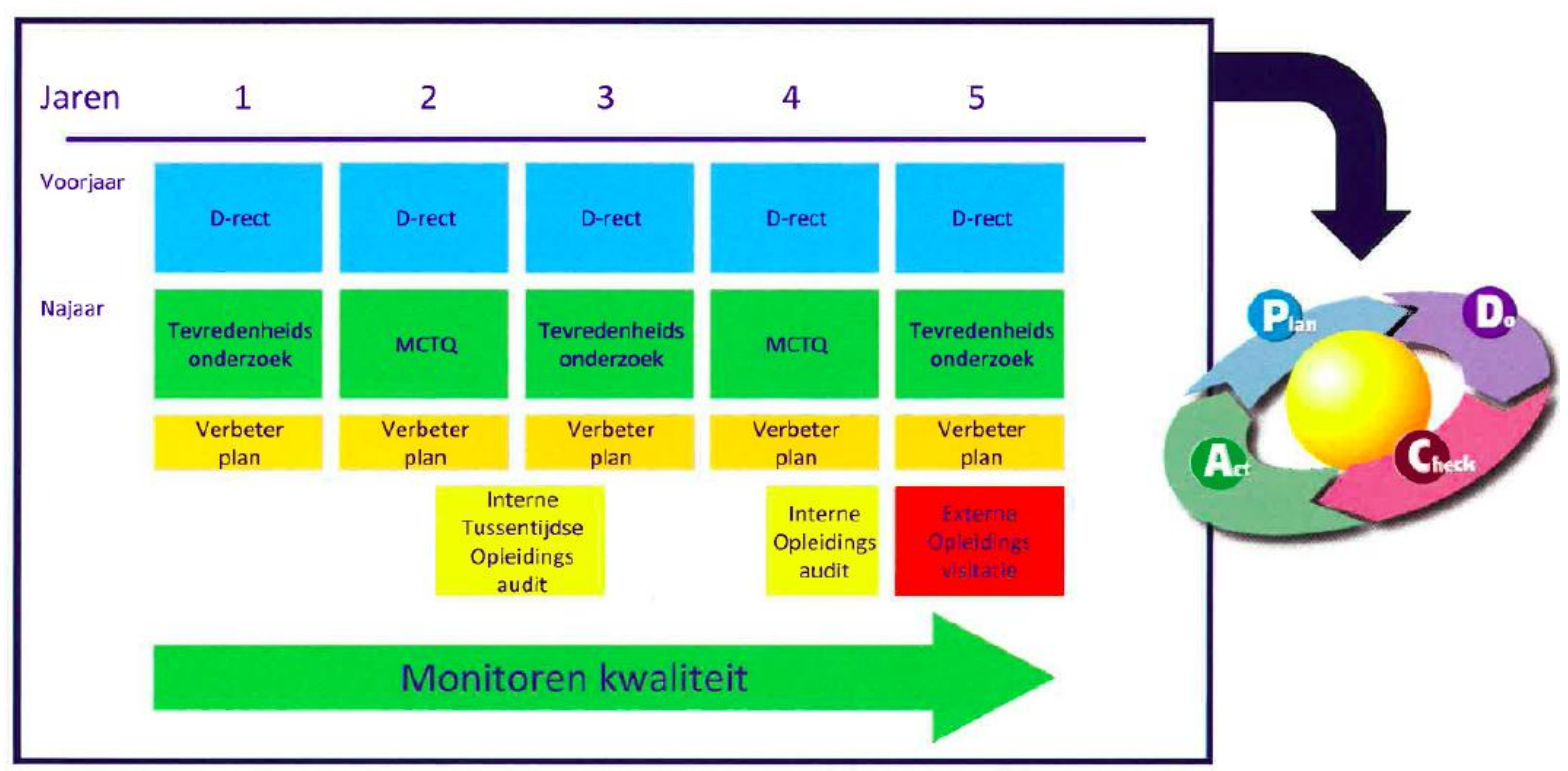

Daarom zijn wij eind jaren negentig begonnen met het opzetten van een intern audit systeem. Mijn oude collega Rob Schipper was één van de initiatiefnemers hiervan. De grondgedachte daarbij was, dat het zo zou moeten zijn dat er een intrinsieke wil aanwezig zou moeten zijn om jezelf continu te verbeteren, volgens een PDCA, een plando-check-act cyclus. Uiteindelijk heeft dit geresulteerd in jaarlijkse evaluaties van de kwaliteit van de opleidingen middels interne enquêtes en interne audits, waarvan u hier een overzicht ziet. Hiermee worden alle opleidingen tenminste $2 \mathrm{x}$ per jaar beoordeeld met verschillende instrumenten. Op grond van deze beoordelingen dienen de opleiders samen met de aios vervolgens verbeterplannen op te stellen en uit te voeren. 
Daarnaast zijn er cursussen ontwikkeld voor de assistenten om met name invulling te geven aan de ontwikkeling van de niet medische competenties en cursussen voor de opleiders om hen te trainen in de vaardigheden van het opleiden.

Ter ondersteuning van de ontwikkeling van de medische handvaardigheden werd een skills laboratorium ingericht, waar assistenten vaardigheden kunnen oefenen alvorens deze te verrichten bij de patiënt zelf. Dit heeft een belangrijke bijdrage geleverd aan de patiëntveiligheid. Onder de bezielende leiding van Jack Jakimowicz en later ook Ad Hendrikx heeft dit geleid tot inmiddels 8 afgeronde promotie-onderzoeken naar de effecten van dit simulatie onderwijs.

Een laatste ontwikkeling zijn de team trainingen die nu onder andere op de IC en SEH regelmatig verricht worden en vooral beogen de samenwerking en daarmee de patiëntveiligheid in acute situaties te bevorderen.

Om alle onderwijskundige vernieuwingen verder in goede banen te leiden en de opleiders daarbij te ondersteunen werden in veel opleidingsziekenhuizen onderwijskundigen aangesteld, waarmee eindelijk onderwijskundige expertise ingebracht kon worden in de medische specialistische vervolgopleidingen.

\section{Regionale ontwikkelingen}

Dan wil ik nu overgaan op de regionale ontwikkelingen. In 2005 verscheen het NFU visie document 'OORzaak en gevolg' waarin de visie van de Nederlandse Federatie van Universiteiten werd neergelegd met betrekking tot het opleiden van artsen in de initiële fase en de fase van de medische specialistische vervolgopleidingen. ${ }^{14}$ Dit heeft geleid tot 8 onderwijs en opleidingsregio's (OOR) gecentreerd rondom de universitaire centra. Zo ontstond ook het OOR Zuid-oost Nederland (OORZON) rond het MUMC+.

In haar visiedocument van 2006 wordt aangegeven dat het het streven is van de OORZON om te komen tot een regio waarin optimaal samengewerkt wordt voor wat betreft:

1. De zorg voor de patiënten in de regio;

2. De opleiding van artsen; en

3. Het wetenschappelijk onderzoek.

Dit onder het motto, 'Niemand heeft alles, samen hebben we veel'.

Het vroeg initiëren van wetenschappelijk onderzoek tijdens de opleiding werd als speerpunt benoemd, waarbij ernaar gestreefd zal worden dat tenminste $20 \%$ van de aios gepromoveerd zullen zijn als zij klaar gekomen zijn met hun opleiding. Op de lange termijn kan op deze wijze een 'Academische Gezondheidsregio' ontstaan met een samenhangend geheel van opleidingen en waar mogelijk gezamenlijke onderzoekslijnen worden gerealiseerd. Uit een onderzoek van o.a. Peeters, de voorzitter van de RvB van het MUMC+, die heeft gekeken naar de kwaliteit van het medisch wetenschappelijk onderzoek van UMC's en perifere opleidingsziekenhuizen in de periode van 1998 tot 2010 blijkt ook dat daar waar samengewerkt wordt tussen UMC's en perifere opleidingsziekenhuizen de kwaliteit van het onderzoek omhoog gaat. ${ }^{15}$ 
Figuur 12. Kwaliteit medische wetenschappelijk onderzoek in Nederland.

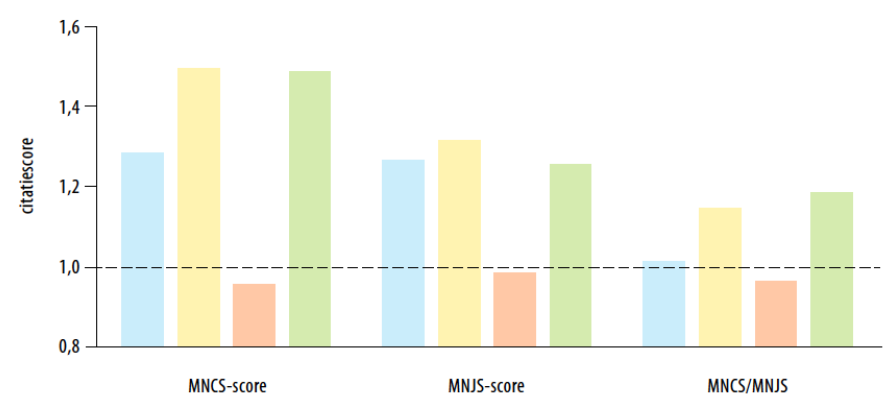

Legenda: 'Mean normalized citation score' (MNCS) en 'mean normalized journal score' (MNJS) alsmede het quotiënt van deze 2 scores voor publicaties uit STZ-centra (licht blauwe kolom), UMC's (gele kolom) en publicaties van STZ-centra zonder (rode kolom) of met (groene kolom) betrokkenheid van UMC's. Deze indicatoren betreffen artikelen gepubliceerd in de periode 1998-2010 (STZ = samenwerkende topklinische opleidingsziekenhuizen).

Inmiddels is er een nauwe samenwerking tussen de verschillende opleidingsklinieken op gang gekomen wat onder andere geleid heeft tot een regionaal kwaliteitszorgplan voor de opleidingen, regionale opleidingsplannen en onderlinge visitaties.

Waar staan we nu?

Uit het voorgaande blijkt dat er veel gebeurd is met het oog op het verbeteren van de kwaliteit in de medische specialistische vervolgopleidingen. Dat roept de vraag op: 'Hoe doen we het nu eigenlijk'?

Figuur 13. Toetsmatrix van de opleiding Obstetrie en gynaecologie

\begin{tabular}{|c|c|c|c|c|c|c|}
\hline Toetsing & Jaar 1 & Jaar 2 & Jaar 3 & Jaar 4 & Jaar 5 & Jaar 6 \\
\hline $\begin{array}{l}\text { Voortgangsgesprek } \\
\text { Alle competenties }\end{array}$ & $4 \times \oplus$ & $4 x \odot$ & $2 \times \oplus$ & $2 \times \oplus$ & $2 x \oplus$ & $2 x \oplus$ \\
\hline $\begin{array}{l}\text { Stagebeoordeling } \\
\text { Alle competenties }\end{array}$ & $4 \times \odot$ & $4 \times \odot$ & $3 \times \oplus$ & $3 \times \oplus$ & nvt & nvt \\
\hline $\begin{array}{l}\text { Geschiktheidbeoordeling } \\
\text { Alle competenties }\end{array}$ & () & ()ㅜ & ()ㅜ & 구 & ()ㅜ & ()ㅜ \\
\hline $\begin{array}{c}\text { Multisource feedback } \\
\text { Communicatie, } \\
\text { samenwerking, organisatie } \\
\text { en professionaliteit }\end{array}$ & $1 \times \oplus$ & nvt & nvt & $1 \times \oplus$ & nvt & nvt \\
\hline $\begin{array}{l}\text { CAT (Critical Appraised } \\
\text { Topic) } \\
\text { Kennis en wetenschap, } \\
\text { organisatie }\end{array}$ & $2 x \oplus$ & $2 x \odot$ & $2 x \odot$ & $2 \times \odot$ & $2 x \odot$ & $2 x \odot$ \\
\hline $\begin{array}{c}\text { Referaat } \\
\text { Kennis en wetenschap, } \\
\text { organisatie }\end{array}$ & $1 \times \oplus$ & $1 \times \oplus$ & $1 x \oplus$ & $1 \times \oplus$ & $1 \times \oplus$ & $1 \times \oplus$ \\
\hline $\begin{array}{c}\mathrm{KPB} / \mathrm{KPB}^{\ominus} \\
\text { Alle competenties }\end{array}$ & $\begin{array}{c}>10 \text { per } \\
\text { jaar }\end{array}$ & $\begin{array}{c}>10 \text { per } \\
\text { jaar }\end{array}$ & $\begin{array}{c}>10 \text { per } \\
\text { jaar }\end{array}$ & $\begin{array}{c}>10 \text { per } \\
\text { jaar }\end{array}$ & $\begin{array}{c}\text { >10per } \\
\text { jaar }\end{array}$ & $\begin{array}{c}>10 \text { per } \\
\text { jaar }\end{array}$ \\
\hline $\begin{array}{c}\text { OSATS } \\
\text { Medisch handelen }\end{array}$ & $\geq 20$ & $\geq 20$ & $\geq 20$ & $\geq 20$ & $\geq 20$ & $\geq 20$ \\
\hline $\begin{array}{l}\text { Cursorisch onderwijs } \\
\text { (10 dagen per jaar) } \\
\text { Alle competenties }\end{array}$ & 10 dagen & 10 dagen & 10 dagen & 10 dagen & 10 dagen & 10 dagen \\
\hline $\begin{array}{l}\text { Artikel of voordracht } \\
\text { Kennis en wetenschap }\end{array}$ & \multicolumn{6}{|c|}{$\begin{array}{l}\text { Minimaal één voordracht of presenteert één poster of publiceert ten minste } \\
\text { één artikel in een wetenschappelijk tijdschrift of medisch vakblad, tijdens de } \\
\text { opleiding tot specialist. }\end{array}$} \\
\hline
\end{tabular}


Uit een recente enquête van de projectgroep Modernisering van de Medische Vervolgopleidingen onder de opleiders is gebleken dat er veel geklaagd wordt over de bureaucratie van het nieuwe opleiden en dat er niet altijd voldoende aandacht is voor de niet medische competenties. ${ }^{16,17}$

Voor wat betreft de bureaucratie: deze betreft enerzijds het vele papierwerk, soms zelfs tot meer dan 1000 pagina's, wat voor een externe visitatie moet worden ingevuld en anderzijds de genoemde verplichte evaluaties van de aios, waarbij men sterk het gevoel heeft dat het belangrijker is dat men de geëiste aantallen haalt, dan dat er gekeken wordt naar de inhoudelijke kwaliteit. U ziet hier een overzicht van de verplichte evaluaties van één van medische specialistische vervolgopleidingen.

Dat de kwaliteit van de gegeven feedback in onze opleidingscultuur voor verbetering vatbaar is, is ook gebleken uit het onderzoek van Christopher Watling, in januari van dit jaar gepromoveerd aan deze universiteit op zijn proefschrift Cognition, Culture and Credibility. ${ }^{18}$ Hij vond, dat wil feedback geloofwaardig en daarmee betekenisvol zijn voor de aios, dit afhangt van verschillende factoren:

1. Persoonlijke factoren waarvan reflectie er één is. Hoe verhoudt de gegeven feedback zich met de eigen perceptie? Is de aios het ermee eens of niet? Als namelijk de feedback niet resoneert met de eigen reflectie dan is de kans groot dat er geen leereffect vanuit zal gaan.

2. Van factoren van de gegeven feedback zelf. Komt de feedback authentiek over en snijdt deze hout? Maar al te vaak komt het voor dat de gegeven feedback namelijk te algemeen en niet specifiek genoeg is, zoals bijvoorbeeld 'je kennis kan nog verbeterd worden', wat natuurlijk altijd geldend is. Verder bleek er vaak geen actieplan en follow-up moment gekoppeld te worden aan de feedback, met als gevolg een vermindering van de kansen op een leereffect.

3. Ten derde hangt de waarde van de gegeven feedback ook af van de cultuur waarin deze gegeven wordt. Vergeleken met bijvoorbeeld het onderwijs op het conservatorium, waar het normaal is dat er continu feedback gegeven wordt door directe observaties en door een persoonlijke leraar waarmee men een vertrouwensband heeft kunnen opbouwen, is dit in de geneeskunde vaak niet het geval. Feedback wordt namelijk lang niet altijd gegeven naar aanleiding van directe observaties, en doordat men stages loopt op verschillende afdelingen en vaak ook nog in verschillende ziekenhuizen worden langdurige opleider/aios relaties niet bevorderd.

Hij pleit er dan ook voor om een verandering in de opleidingscultuur te bewerkstelligen waar het geven van direct geobserveerde feedback genormaliseerd wordt, aios/opleider relaties bevorderd worden, waar samen met de aios heldere doelen gedefinieerd worden, en deze voorzien worden van een actieplan en ook opgevolgd gaan worden. Daarbij moeten we ons naar mijn mening realiseren dat we continu aan het opleiden zijn. Ook als we geen formele feedback geven, elk moment van de dag waar we contact 
hebben met of gedrag observeren van een aios zou als een opleidingsmoment gezien kunnen en misschien wel moeten worden. Op die manier kunnen opleider en aios zo optimaal mogelijk gebruik maken van de opleiding. Probleem is dat dit kan gaan wringen met de praktijk, immers vaak staat de volgende patiënt weer voor de deur. We zullen dan ook moeten accepteren dat opleiden tijd kost en daar in de organisatie van onze werkzaamheden rekening mee moeten gaan houden. Ik ben bang dat dit lang niet altijd het geval zal zijn. Vandaar ook dat de Accreditation Council for Graduate Medical Education in de VS het CLER (Clinical Learning Environment Review) programma heeft geïnitieerd wat beoogd een effectieve en veilige leeromgeving voor de aios te bewerkstelligen. ${ }^{19}$

Tot slot liet Westerman in zijn onderzoek zien dat jonge klare specialisten zich met name op het terrein van de niet medisch competenties onvoldoende voorbereid voelden, hetgeen ook correleerde met de kans op het krijgen van een burn out. ${ }^{20.21}$

Dit alles overziend zijn er mijns inziens momenteel de volgende aandachtspunten te benoemen:

1. De opleidingscultuur in de opleidingsziekenhuizen en de kwaliteit van de gegeven feedback. Dit vergt een verbetering van de opleiding van de opleiders als teachers. Momenteel bestaat deze in onze regio uit een Basic Clinical Teaching cursus van 2 dagen en een basistraining toetsing op de werkplek van 1 dag. Als docent bij deze laatste cursus wil ik daar graag mijn steentje aan bijdragen. Overigens kan men zich afvragen of deze 3 dagen voldoende zijn om voldoende geschoold te worden als opleider. Persoonlijk denk ik van niet en het zou met niet verbazen als dit in de toekomst nog aangepast zal gaan worden.

2. Het verminderen van de bureaucratie rondom de opleidingen. Het RGS en CGS hebben hiertoe al initiatieven ondernomen, hetgeen geresulteerd heeft in een visiedocument 'Van handhaven naar verbeteren'. ${ }^{22}$ In het kader hiervan is door het CGS en RGS een werkgroep ingesteld die het rapport 'Kwaliteitszorg voor de medische specialistische vervolgopleidingen'23 ${ }^{23}$ al moeten gaan actualiseren met als doel te komen tot een adequaat functionerend intern kwaliteitszorgsysteem voor deze opleidingen. Eén en ander heeft als doel om kwaliteit van de opleidingen intern te borgen. Indien er sprake is van een adequaat functionerend intern kwaliteitszorgysteem voor de opleidingen zou de externe RGS visitatie minder zwaar gemaakt kunnen worden. Als lid van het CGS en deze projectgroep, die onder leiding staat van Albert Scherpbier, wil ik mij daar graag voor inzetten.

3. Er zal meer aandacht moeten komen voor de ontwikkeling van de niet medische competenties van onze aios. Onze regio wil dat vooral doen door ons te focussen op doelmatigheid in de zorg en opleiding. Inmiddels zijn de eerste stappen hiervoor al gezet. Samen met mijn collegae, waaronder Laurents Stassen, Ide Heyligers, Scheltus van Luik en vele anderen in de OORZON wil ik graag mijn bijdrage hieraan leveren.

4. Het beter gaan monitoren van wat we nu eigenlijk beogen met onze opleiding: namelijk het opleiden van specialisten die straks voldoende toegerust zijn op de taken die hen wachten. Daartoe hebben we een 'alumni enquête' ontwikkeld, die we 
bij onze 'oud aios' ongeveer een half jaar nadat zij klaar gekomen zijn met de opleiding willen gaan uitzetten. Op deze manier hopen we van onze aios te horen in hoeverre zij zich, nu ze de praktijk hebben kunnen ervaren, adequaat voorbereid voelen op de uitoefening van hun specialisme en op welke terreinen de opleiding wellicht nog verbeterd kan worden.

Tot slot wil ik kort ingaan op nieuwe ontwikkelingen die in de naaste toekomst voor ons liggen:

Korting op de opleidingen?

Ten eerste de korting op de opleidingsduur. Ingegeven door de noodzaak tot bezuinigingen had de Minister het voornemen de duur van de medische specialistische vervolgopleidingen te verkorten. Dit hoewel de duur van onze opleidingen op een gemiddeld niveau van die in Europa liggen..$^{24}$ Voor de longgeneeskunde zou een korting van de opleidingsduur van 6 naar 4 jaar voorgenomen zijn. Dit terwijl de European Respiratory Society nu net de Eindtermen en het bijbehorend curriculum met een duur van 6 jaar heeft vastgesteld ${ }^{25}$ en waaraan men een Europees longartsenexamen aan heeft gekoppeld. Aan beide projecten, welke mede ten doel hadden om een veilige uitwisseling van longartsen binnen Europa te kunnen borgen, heb ik mogen meewerken. Gelukkig is het tot een dergelijke uitzonderlijk grote korting, welke ons in Europa duidelijk tot een buitenbeentje had gemaakt, niet gekomen. Afgesproken is om nu een korting te halen door competenties die studenten in het laatste jaar voor hun artsexamen opdoen in een zogenaamd schakeljaar, mee te laten tellen in de vervolgopleiding en aios die sneller hun competenties halen gedurende hun opleiding, sneller te laten doorstromen. Het is de bedoeling om op deze manier $80 \%$ van de aios zes maanden korting te laten behalen op hun totale opleidingsduur in 2022.

Figuur 14. Gemiddelde opleidingsduur in Nederland.

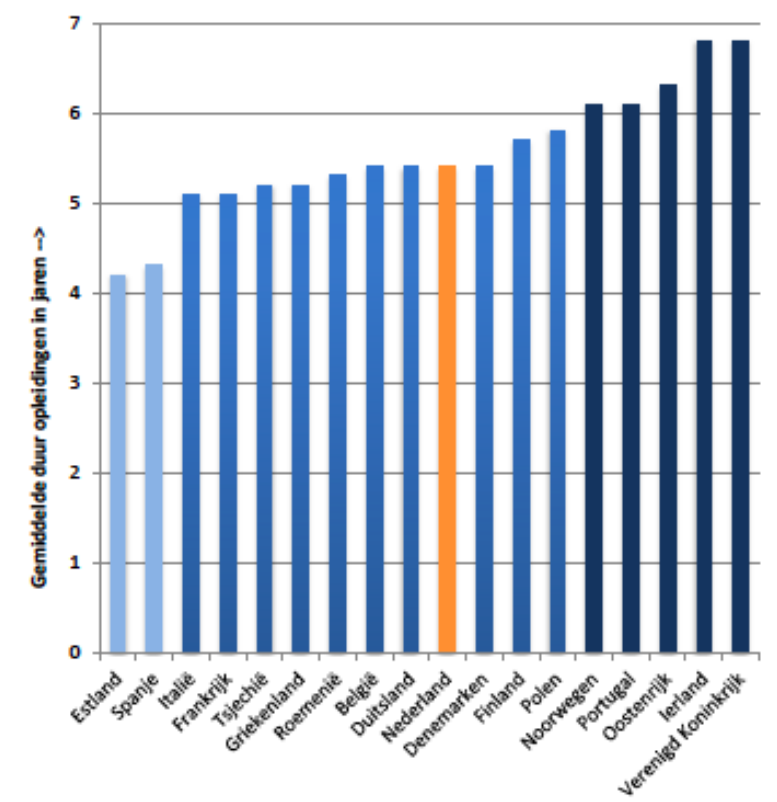


Beoordelen progressie competenties? Milestones en/of EPA's

Om de progressie van de aios beter te kunnen monitoren zullen de Canadezen en Amerikanen in hun nieuwe opleidingsplannen waarschijnlijk zogenaamde 'Milestones' gaan introduceren. ${ }^{26-28}$ Een 'Milestone' wordt daarbij gedefinieerd als een bepaald niveau in competentie dat de aios op een bepaald moment in zijn opleiding bereikt moet hebben. Hoewel het de bedoeling is hiermee de bureaucratie te verminderen vraag ik me af of dit zal gaan werken: immers de internisten in de VS hebben vanuit de 6 door hen gedefinieerde kerncompetenties, meer dan 40 subcompetenties afgeleid waaruit meer dan 140 te evalueren 'milestones' zijn ontstaan.

Figuur 15. EPA's/Thema's opleiding Obstetrie en gynaecologie (samengevat)

\begin{tabular}{|l|l|l|l|l|l|}
\hline $\begin{array}{l}\text { Bekwaamheidsniveau (1 } \\
\text { t/m 5) }\end{array}$ & $\begin{array}{l}1 \\
\text { Heeft kennis } \\
\text { van }\end{array}$ & $\begin{array}{l}2 \\
\text { Handelt } \\
\text { onder } \\
\text { strenge } \\
\text { supervisie }\end{array}$ & $\begin{array}{l}3 \\
\text { Handelt met } \\
\text { beperkte } \\
\text { supervisie }\end{array}$ & $\begin{array}{l}4 \\
\text { Handelt } \\
\text { zonder } \\
\text { supervisie }\end{array}$ & $\begin{array}{l}5 \\
\text { Superviseert en } \\
\text { onderwijst bij de } \\
\text { handeling }\end{array}$ \\
\hline
\end{tabular}

\begin{tabular}{|l|l|l|l|}
\hline $\begin{array}{l}\text { Thema's versus 3 IJkpunten (I, II en III) op } \\
\text { bekwaamheidsniveau (1t/m5) }\end{array}$ & $\begin{array}{l}\text { IJkpunt I } \\
\mathbf{2} \text { jaar }\end{array}$ & $\begin{array}{l}\text { IJkpunt II } \\
\mathbf{4} \text { jaar }\end{array}$ & $\begin{array}{l}\text { IJkpunt III } \\
\mathbf{6} \text { jaar } \\
\text { (differentiatie) }\end{array}$ \\
\hline Zwangerschapsbegeleiding ongecompliceerd & 5 & 3 & \\
\hline Basis Zwangerschapsbegeleiding gecompliceerd & 3 & 4 & \\
\hline Gewone bevalling & 5 & 3 & \\
\hline Gecompliceerde bevalling & 3 & 3 & \\
\hline Basis Gecompliceerde bevalling hoog ingeschat risico & 3 & & \\
\hline Kraamperiode \& kind ongecompliceerd & 5 & 4 & \\
\hline Kraamperiode\& kind gecompliceerd & 3 & 4 & \\
\hline Endocrinologie \& Fertiliteit basaal & 2 & 4 & \\
\hline
\end{tabular}

In Europa neigt men ertoe dit te gaan doen met behulp van de zogenaamde EPA's ('Entrustable Professional Activities').29,30 Dit wordt gedefinieerd als een essentieel en goed te omschrijven onderdeel van het specialisme. Bijvoorbeeld voor de gynaecologie, die dit al hebben ingevoerd: de ongecompliceerde of de gecompliceerde bevalling. Door observatie in de praktijk wordt dan beoordeeld of en in welke mate men dit deel van het vak aan een aios kan toevertrouwen. Dit levert mijns inziens een overzichtelijker systeem van beoordelen op en voelt voor opleiders intuïtief natuurlijker aan. Op deze manier zullen minder goed functionerende aios sneller geïdentificeerd kunnen worden zodat daar sneller extra begeleiding op gezet kan worden.

\section{Levenslang leren}

Verder is het van belang dat wij onze aios in de toekomst nog meer dan nu het geval is gaan opleiden tot zelf lerende professionals. ${ }^{6}$ Immers de maatschappij en de mogelijkheden voor behandeling veranderen zo snel, dat de professional, om 'up-todate' te blijven, zich zal moeten blijven aanpassen. Een adequate zelfreflectie en het kunnen ontvangen van feedback zijn daarbij een onmisbare eigenschappen. 
Waarschijnlijk zal een dergelijke eis, het regelmatige deelnemen aan evaluatie van en reflecteren op het individueel functioneren en het ontwikkelen en bijhouden van een persoonlijk ontwikkelingsplan, door het CGS aan de nieuwe herregistratie eisen worden toegevoegd.

'Change manager' - 'Verander manager'

Tot slot heeft een internationale groep experts zich gebogen over noodzakelijke toekomstige ontwikkelingen in het medisch onderwijs, dit mede gelet op de bedreigingen die er op ons afkomen, zoals nieuwe infectieziekten, milieu vervuiling, en toenemende risicovol gezondheidsgedrag en dat in een tijd van snelle demografische en epidemiologische veranderingen. ${ }^{4}$ Bovendien wordt de gezondheidszorg steeds complexer en kostbaarder, zodat het in de toekomst waarschijnlijk onmogelijk zal worden om, als er niets veranderd, aan de zorgvraag te kunnen blijven voldoen. Gebleken is dat daar waar artsen betrokken zijn bij de organisatie en het management van de zorg, deze zorgsystemen beter functioneren. ${ }^{31-33}$ Daarom postuleren zij dat we in de toekomst ook artsen zouden moeten opleiden tot 'enlightened change managers', 'verlichte verandermanagers', artsen die verder kunnen denken dan hun eigen vakgebied en instelling, specialisten met een breed maatschappelijk perspectief en een groot maatschappelijk verantwoordelijkheidsgevoel.

\section{Samenvattend}

Samenvattend heb ik u geschetst welke grote veranderingen zich in de afgelopen jaren hebben voorgedaan in de medische specialistische vervolgopleidingen. In korte tijd zijn we erin geslaagd het competentie gericht opleiden vorm te geven. Zeker geen oude wijn in nieuwe zakken. Eerder het op tijd ontkurken van goed gerijpte wijn. Een verandering die nodig was om ook in de toekomst kwalitatief goede medisch specialistische zorg te kunnen blijven bieden.

Maar we zijn er nog niet. Met name de opleidingscultuur binnen de ziekenhuizen, de ontwikkeling van de niet medische - en van 'levens-lang-leren' competenties kan nog verbeterd worden. Daarnaast dient de invulling van de rol van de specialist als 'Change Manager' en de ontwikkeling van onze regio naar een echte 'Academische gezondheidsregio' verder vorm gegeven te worden.

Tot slot biedt de instelling van deze leerstoel die verbonden is aan de School of Health Professions Education, onder leiding van Cees van der Vleuten, de unieke mogelijkheid om de expertise die er op het gebied van het medisch onderwijs hier in Maastricht bestaat verder te innoveren en te gaan implementeren in de medische specialistische vervolgopleidingen, alsmede de effecten daarvan te gaan onderzoeken.

Ik beschouw het dan ook als een bijzonder voorrecht dat het mij gegeven is om in de naaste toekomst verder invulling te geven aan de kwaliteitsverbetering van de medische specialistische vervolgopleidingen naast datgene dat mij bijzonder dierbaar is, namelijk de patiëntenzorg en de opleiding van onze nieuwe collega's.

Tot slot een woord van dank aan een ieder die het mogelijk heeft gemaakt dat ik hier nu kan en mag staan. In het bijzonder wil ik noemen: 
De leden van het College van Bestuur van deze Universiteit, van de Raad van Bestuur van het MUMC+, in het bijzonder de Decaan Albert Scherpbier, van de Raad van Bestuur van het Catharina ziekenhuis, en van het College van Toezicht. Ik dank hen zeer voor het door hen in mij gestelde vertrouwen.

Mijn opleiders en mijn latere maten: Cees Jansveld, Harm Gooszen en Rob Schipper: dank voor de fantastische opleiding die ik van jullie heb gekregen.

Piet Postmus, die mij enthousiast heeft weten te maken voor de wetenschap.

Harry Crebolder, mijn promotor en Luc de Witte, mijn co promotor. Dank voor jullie begeleiding tijdens mijn promotie onderzoek, veel heb ik van jullie mogen leren.

Miel Wouters en Joop van den Bergh, dank voor de vruchtbare samenwerking in onze onderzoeken naar COPD en osteoporose.

Miel Wouters en Erik van Haren, dank voor de plezierige manier waarop wij gezamenlijk de opleiding longgeneeskunde in onze regio vorm hebben geven.

Mijn huidige maten, Jacques Creemers, Pascal Wielders, Ben van den Borne, Roland van Balkom en Hans de Beer, dank jullie voor jullie geduld met mij, het opvangen van mijn vele afwezigheid in verband met mijn vele nevenfuncties, alleen met jullie hulp en steun hebben we dit mogelijk kunnen maken.

Verder mogen alle medewerkers van het OORZON bureau, het bureau 0 \& 0 van het Catharina ziekenhuis, de assistenten longgeneeskunde, alle medewerkers van de afdeling longgeneeskunde, natuurlijk niet vergeten worden. Dank voor alle steun en samenwerking bij het altijd streven naar het optimale zowel in de opleiding als de behandeling van onze patiënten.

Tot slot de belangrijksten in mijn leven.

Mijn ouders. Bijzonder veel waardering heb ik voor hen, voor de wijze waarop zij er altijd voor mij en mijn 5 broers en zussen, waren, ons 'wel en wee' altijd voorop stelden en ons een veilige omgeving gaven waar wij ons konden ontwikkelen tot wie we nu zijn. Dankbaar ben ik dan ook dat mijn moeder deze dag nog mag meemaken.

Mijn kinderen, Anne, Wouter en Michiel. Trots ben ik om te zien hoe jullie je, soms met vallen en opstaan, weten te ontwikkelen tot heel bijzondere personen, ieder met jullie eigen bijzondere kwaliteiten.

En als allerlaatste mijn allerliefste Anneke, nu al voor meer dan 25 jaar samen, zonder jou steun en begrip had ik hier niet kunnen staan. Woorden schieten tekort om te beschrijven wat jij voor mij betekent.

Ik heb gezegd.

\section{Referenties:}

1. Hillen H. Eerste hoogleraar geneeskunde Maastricht: Pelerin [First professor of medicine in Maastricht: Pelerin]. Nederlands tijdschrift voor geneeskunde 2010;154:A1525.

2. Lindeboom GA. Geschiedenis van de medische wetenschap in Nederland. Bussum: Fibula-Van Dishoeck; 1973. 
3. Engelfriet A. De geschiedenis van de gilden van Rotterdam. Accessed at: http://www.engelfriet.net/Alie/Hans/Gilden.htm.

4. Frenk J, Chen L, Bhutta ZA, et al. Health professionals for a new century: transforming education to strengthen health systems in an interdependent world. Lancet 2010;376:1923-58.

5. Björnberg A. Euro Health Consumer Index 2013. Report. Health Consumer Powerhouse Ltd. Brussels, Belgium. Nov 28, 2013. Accessed at: http://www.healthpowerhouse.com/index.php?Itemid=55.

6. Orde Medisch Specialisten. Visiedocument De medisch specialist 2015. Accessed at: http://www.orde.nl/assets/structured-files/OVER\%200MS\%20MEDISCH\%20SPECIALIST\%202015/Visiedocument\%20web.pdf

7. Zorgverzekeraars Nederland. Praktijkvariatierapport rughernia 2013. Accessed at: https://www.zn.nl/nieuws/pers/persbericht/?newsId=08fa451f-71fd-4dcc-be18b8ad9aa44888.

8. http://www.royalcollege.ca/portal/page/portal/rc/canmeds.

9. Miller GE. The assessment of clinical skills/competence/performance. Academic medicine: journal of the Association of American Medical Colleges 1990;65:S63-7.

10. van der Vleuten CP, van Luyk SJ, Swanson DB. Reliability (generalizability) of the Maastricht Skills Test. Research in medical education: proceedings of the annual Conference Conference on Research in Medical Education 1988;27:228-33.

11. Norcini JJ, Jr. Standards and reliability in evaluation: when rules of thumb don't apply. Academic medicine : journal of the Association of American Medical Colleges 1999;74:1088-90.

12. Meininger AK. De medisch specialist van straks - Basisartsen die in een ziekenhuis aan de slag willen, zullen in de toekomst een opleiding moeten volgen. Een pleidooi voor kwaliteit, taakdifferentiatie en efficiency in de medische vervolgopleidingen. Medisch contact : officieel orgaan van de Nederlandsche Maatschappij tot Bevordering der Geneeskunst 2010;65:729-32.

13. Lucas A. Support of an asthma/COPD service for general practitioners in daily practice. Drukkerij Gildeprint. Enschede, 2013.

14. NFU. OOR-zaak en gevolg. Opleidingen in de zorg. NFU visiedocument 2005. Accessed at: http://www.nfu.nl/img/pdf/NFU_Oorzaak.pdf.

15. Levi M, Sluiter HE, van Leeuwen T, Rook M, Peeters G. Medisch-wetenschappelijk onderzoek in Nederland. Hoge kwaliteit door samenwerking UMC's en opleidingsziekenhuizen. [Biomedical research in the Netherlands: high quality due to cooperation between University Medical Centers and non-academic large teaching hospitals]. Nederlands tijdschrift voor geneeskunde 2013;157:A6081.

16. Projectgroep Modernisering Medisch Vervolgopleidingen. Implementatie Modernisering Medische Vervolgopleidingen. Enquête onder opleiders. MMV; 22 augustus 2013. Report No.: 818 | MMV KNMG. Accessed at: http://knmg.artsennet.nl/Opleiding-en-herregistratie/Project-MMVHome/Actueel/nieuwsbericht-1/138778/Uitkomsten-enquete-onder-opleiders.htm. 
17. Dörr PJ, Scheele F. Competentieonderwijs blijft haken. Medisch contact : officieel orgaan van de Nederlandsche Maatschappij tot Bevordering der Geneeskunst 2011;66:1345-7.

18. Watling CJ. Cognition, culture and credibility. Deconstructing feedback in medical education. Datawyse. Universitaire Pers Maastricht, 2014.

19. Accreditation Council for Graduate Medical Education. CLER Pathways to Excellence Expectations for an optimal clinical learning environment to achieve safe and high quality patient care. Executive summary, 2014. Accessed at:

http://www.acgme.org/acgmeweb/portals/0/PDFs/CLER/CLER_ExecutiveSum.pdf. 20. Westerman M, Teunissen PW, Fokkema JP, et al. The transition to hospital consultant and the influence of preparedness, social support, and perception: A structural equation modelling approach. Medical teacher 2013;35:320-7.

21. Westerman M, Teunissen PW, Jorgensen RL, et al. The transition to hospital consultant: Denmark and the Netherlands compared on preparedness for practice, perceived intensity and contextual factors. Medical teacher 2013;35:481-9.

22. http://www.orde.nl/assets/structured-files/AFB

DOWNL_OPLEIDING/DOWNLOADS_OPLEIDING/Strategiedocument Van Handhaven naar Verbeteren.pdf.

23. Scherpbier AJJA. Kwaliteitszorg voor de specialistische vervolgopleiding. Accessed at: http://knmg.artsennet.nl/Opleiding-en-herregistratie/Project-MMVHome/Rubrieken/Zelfevaluatietool.htm.

24. LJS Medisch Projectbureau. Eindrapportage Quickscan Opleidingsduur en Bekostiging Medisch Specialistische Vervolgopleidingen in de EU.2013 11 april 2013. Accessed at: file:///Users/franksmeenk/Downloads/eindrapportage-quickscanopleidingsduur-en-bekostiging-medisch-specialistische-vervolgopleidingen-in-de-eu.pdf 25. Loddenkemper R, Haslam PL, Séverin T, et al. European Curriculum Recommendations for Training in Adult Respiratory Medicine. Breathe 2008;5:80-93. 26. Nasca TJ, Philibert I, Brigham T, Flynn TC. The next GME accreditation system-rationale and benefits. The New England journal of medicine 2012;366:1051-6.

27. http://www.royalcollege.ca/portal/page/portal/rc/canmeds/canmeds2015.

28. Green LM, Aagaard EM, Caverzagie KJ et al. Charting the road to competence: Developmental milestones for internal medicine residency training. J Grad Med Ed 2009; 1: 5-20.

28. ten Cate 0 , Scheele F. Competency-based postgraduate training: can we bridge the gap between theory and clinical practice? Academic medicine : journal of the Association of American Medical Colleges 2007;82:542-7.

30. Driessen E, Scheele F. What is wrong with assessment in postgraduate training? Lessons from clinical practice and educational research. Medical teacher 2013;35:56974.

31. Coltart CE, Cheung R, Ardolino A, et al. Leadership development for early career doctors. Lancet 2012;379:1847-9.

32. Ham C, Dickinson H. Engaging Doctors in Leadership: What we can learn from international experience and research evidence. NHS Institute for Innovation and 
Improvement 2008. Accessed at: http://www.aomrc.org.uk/doc_view/198-engagingdoctors-what-can-we-learn-from-international-experience-and-research-evidence.

33. Baker GR. The roles of leaders in high-performing health care systems. The Kings Fund 2011. Accessed at: http://www.kingsfund.org.uk/sites/files/kf/roles-of-leadershigh-performing-health-care-systems-ross-baker-kings-fund-may-2011.pdf. 